\title{
Classical Enterotoxin Genes of Staphylococcus aureus Isolated from the Raw Milk of Cows and Goats in Yogyakarta Indonesia
}

\author{
Desy Cahya Widianingrum ${ }^{1}$, Sarasati Windria ${ }^{2}$, Fatkhanuddin Aziz ${ }^{3}$, Siti Isrina \\ Oktavia Salasia ${ }^{1,4^{*}}$ \\ ${ }^{1}$ Department of Animal Science, Faculty of Agriculture, University of Jember, 68121 Jember, Indonesia \\ ${ }^{2}$ Division of Microbiology, Department of Basic Medical Science, Study Program of Veterinary Medicine, Faculty of \\ Medicine, Padjadjaran University, 45363 Bandung, Indonesia \\ ${ }^{3}$ Department of Bioresources Technology and Veterinary, Vocational College, Universitas Gadjah Mada, 55281 \\ Yogyakarta, Indonesia \\ ${ }^{4}$ Department of Clinical Pathology, Faculty of Veterinary Medicine, Universitas Gadjah Mada, 55281 Yogyakarta, \\ Indonesia \\ *Corresponding author. Email: isrinasalasia@ugm.ac.id
}

\begin{abstract}
Milk is a highly nutritious food containing several essential nutrients. Consequently, it can be contaminated by pathogenic bacteria, including Staphylococcus aureus. This study aimed to analyze the genes encoding nine classical enterotoxins of $S$. aureus isolated from cow and goat raw milk. A total of $75 \mathrm{~S}$. aureus isolates were obtained from milk samples of dairy cows (46 isolates) and Peranakan Etawa (PE) goats (29 isolates) from different farms in Yogyakarta Indonesia. Based on the cultural and biochemical properties and the 23S rRNA occurrence, all isolates could be identified as $S$. aureus. The seh gene was the most frequently observed in 21 isolates (45.65\%) of cows, followed by the sea gene (in 8 isolates, 17.39\%), the seg and the sei genes (each in 4 isolates, 8.69\%). The sec is the only staphylococcal enterotoxin gene observed in $S$. aureus isolated from goat milk with the prevalence of $6.89 \%$. The genes encoding four out of nine classical enterotoxins (seh, sea, seg, and sei) are commonly isolated from S. aureus in cow milk, but only sec gene can be found in the isolates from goat milk.
\end{abstract}

Keywords: Staphylococcus aureus, enterotoxin gene, dairy raw milk, multiplex PCR

\section{INTRODUCTION}

Staphylococcus aureus is an important agent of subclinical mastitis in dairy animals. It is known as one of the leading causes of foodborne illness and food poisoning outbreak worldwide [1]. The presence of $S$. aureus and genes encoding staphylococcal enterotoxin (SE) in livestock products is hazardous for consumer health [2]. Foods containing SE are the main cause of foodborne diseases [3,4]. $S$. aureus strains from mastitis cases were reported to be capable of producing toxic shock syndrome toxin-1 (TSST-1) that cause toxic shock syndrome (TSS) [5]. In many countries, the incidence of foodborne disease and food poisoning outbreaks is related to different enterotoxin genes $[6,7,8,9]$.
Initially, the division of classical SE genes consists of sea-see. After the findings of seg, seh, sei, sej, and other SEs, the division of gene develops [10]. Based on this, it is necessary to identify the distribution pattern of SE genes in farm products as an effort to identify and anticipate the treatment and control.

\section{MATERIALS AND METHODS}

This study used $S$. aureus isolated from cow milk (46 isolates) and Etawa goat milk (29 isolates) which collected from several dairy farms in Yogyakarta, Indonesia. The strains were identified as $S$. aureus based on phenotypic and genotypic identifications in the Laboratory of Clinical Pathology, Faculty of Veterinary Medicine, Universitas Gadjah Mada. Phenotypic identifications included mannitol salt agar (MSA), coagulase, Gram staining, catalase, 
and Voges-Proskauer (VP) tests [11]. Genotyping was performed based on the presence of the 23S rRNA, nuc, and coa genes, as described in previous studies by Windria et al. [12].

The detection of enterotoxin encoding genes (seasej) was carried out using two sets of multiplex polymerase chain reaction (PCR) method (Set 1: sea, seb, sec, sed, see; Set 2: seg, seh, sei, sej) [13]. The primers and programs used are presented in Table 1. The PCR products were analyzed by electrophoresis in
3\% agarose gel (Cambrex Bio Science Rockland, Inc. Rockland, ME) stained with $0.5 \mu \mathrm{g} / \mathrm{ml}$ of EtBr, in $0.5 x T B E$ buffer. The PCR products were visualized using a transilluminator.

\section{RESULTS AND DISCUSSION}

Molecular identification confirmed all of $S$. aureus isolates have $23 S$ rRNA, nuc, and coa genes. The results of the analysis of enterotoxin coding genes are presented in Table 2.

Table 1. Oligonucleotide primers and PCR condition used in gene amplification

\begin{tabular}{|c|c|c|c|}
\hline Genes (bp) & Oligonucleotides sequence $\left(5^{\prime}-3^{\prime}\right)$ & PCR condition & Reference \\
\hline $\begin{array}{l}23 S \text { rRNA } \\
(1250) \mathrm{bp})\end{array}$ & $\begin{array}{l}\text { f: ACG GAG TTA CAA AGG ACG AC } \\
\text { r: AGC TCA GCC TTA ACG AGT AC }\end{array}$ & $\begin{array}{l}37 \text { cycles, } 94^{\circ} \mathrm{C} \text { for } 5 \mathrm{~min}, 94^{\circ} \mathrm{C} \\
\text { for } 40 \mathrm{sec}, 64^{\circ} \mathrm{C} \text { for } 60 \mathrm{sec}, 72^{\circ} \mathrm{C} \\
\text { for } 75 \mathrm{sec}, 72^{\circ} \mathrm{C} \text { for } 5 \mathrm{~min}\end{array}$ & [14] \\
\hline nuc (279) & $\begin{array}{l}\text { f: GCG ATT GAT GGT GAT ACG GTT } \\
\text { r: ACG CAA GCC TTG ACG AAC TAA AGC }\end{array}$ & $\begin{array}{l}37 \mathrm{cycles}, 94^{\circ} \mathrm{C} \text { for } 5 \mathrm{~min}, 94^{\circ} \mathrm{C} \\
\text { for } 1 \mathrm{~min}, 55^{\circ} \mathrm{C} \text { for } 30 \mathrm{sec}, 72^{\circ} \mathrm{C} \\
\text { for } 30 \mathrm{sec}, 72^{\circ} \mathrm{C} \text { for } 5 \mathrm{~min}\end{array}$ & {$[15]$} \\
\hline coa & $\begin{array}{l}\text { f: ATA GAG ATG CTG GTA CAG G } \\
\text { r: GCT TCC GAT TGT TCG ATG C }\end{array}$ & $\begin{array}{l}30 \text { cycles, } 94^{\circ} \mathrm{C} \text { for } 5 \min , 94^{\circ} \mathrm{C} \\
\text { for } 1 \text { min, } 58^{\circ} \mathrm{C} \text { for } 1 \text { min, } 72^{\circ} \mathrm{C} \\
\text { for } 1 \text { min and } 72^{\circ} \mathrm{C} \text { for } 5 \text { min }\end{array}$ & {$[16]$} \\
\hline sea (127) & $\begin{array}{l}\text { f: CCTTTGGAAACGGTTAAAACG } \\
\text { r: TCTGAACCTTCCCATCAAAAAC }\end{array}$ & \multirow{9}{*}{$\begin{array}{l}35 \text { cycles, } 95^{\circ} \mathrm{C} \text { for } 15 \mathrm{~min}, 95^{\circ} \mathrm{C} \\
\text { for } 30 \mathrm{sec}, 57^{\circ} \mathrm{C} \text { for } 90 \mathrm{sec} \text {, and } \\
72^{\circ} \mathrm{C} \text { for } 90 \mathrm{sec}, 72^{\circ} \mathrm{C} \text { for } 10 \mathrm{~min}\end{array}$} & {$[17]$} \\
\hline seb (477) & $\begin{array}{l}\text { f: TCGCATCAAACTGACAAACG } \\
\text { r: GCAGGTACTCTATAAGTGCCTGC }\end{array}$ & & {$[17]$} \\
\hline $\sec (271)$ & $\begin{array}{l}\text { f: CTCAAGAACTAGACATAAAAGCTAGG } \\
\text { r: TCAAAATCGGATTAACATTATCC }\end{array}$ & & {$[17]$} \\
\hline sed (319) & $\begin{array}{l}\text { f: CTAGTTTGGTAATATCTCCTTTAAACG } \\
\text { r: TTAATGCTATATCTTATAGGGTAAACATC }\end{array}$ & & {$[17]$} \\
\hline see (178) & $\begin{array}{l}\text { f:CAGTACCTATAGATAAAGTTAAAACAAGC } \\
\text { r: TAACTTACCGTGGACCCTTC }\end{array}$ & & {$[17]$} \\
\hline $\operatorname{seg}(287)$ & $\begin{array}{l}\text { f: AAGTAGACATTTTTGGCGTTCC } \\
\text { r: AGAACCATCAAACTCGTATAGC }\end{array}$ & & [13] \\
\hline $\operatorname{seh}(213)$ & $\begin{array}{l}\text { f: GTCTATATGGAGGTACAACACT } \\
\text { r: GACC TTTACTTATTTCGCTGTC }\end{array}$ & & [13] \\
\hline sei (454) & $\begin{array}{l}\text { f: GGTGATATTGGTGTAGGTAAC } \\
\text { r: ATCCATATTCTTTGCCTTTACCAG }\end{array}$ & & [13] \\
\hline sej (152) & $\begin{array}{l}\text { f: ATAGCATCAGAACTGTTGTTCCG } \\
\text { r: CTTTCTGAATTTTACCACCAAAGG }\end{array}$ & & [10] \\
\hline
\end{tabular}


Table 2. Data of staphylococcus enterotoxin genes from raw milk of cow and goat

\begin{tabular}{|l|c|c|c|c|c|c|c|c|c|c|c|}
\hline \multirow{2}{*}{ Animal } & \multirow{2}{*}{\begin{tabular}{c}
$\mathrm{N}$ \\
\cline { 3 - 14 }
\end{tabular}} & sea & seb & sec & sed & see & seg & seh & sei & sej & Total \\
\hline \multirow{2}{*}{ Cow } & 46 & $\begin{array}{c}8 \\
(17.39 \%)\end{array}$ & 0 & 0 & 0 & 0 & 4 & 21 & 4 & 0 & 37 \\
$(0 \%)$ & $(0 \%)$ & $(0 \%)$ & $(0 \%)$ & $(8.69 \%)$ & $(45.65 \%)$ & $(8.69 \%)$ & $(0 \%)$ & $(80.43 \%)$ \\
\hline \multirow{2}{*}{ Goat } & 29 & $\begin{array}{c}0 \\
(0 \%)\end{array}$ & 0 & 2 & 0 & 0 & 0 & 0 & 0 & 0 & 2 \\
$(0 \%)$ & $(6.89 \%)$ & $(0 \%)$ & $(0 \%)$ & $(0 \%)$ & $(0 \%)$ & $(0 \%)$ & $(0 \%)$ & $(6.89 \%)$ \\
\hline
\end{tabular}

Data in Table 2 showed the distribution of $S$. aureus enterotoxin genes was different in cow and goat. The prevalence of seh, sea, seg and sei genes was $45.65 \%$ (21/46), $17.39 \%$ (8/46), 8.69\% (4/46), and $8.69 \%$ (4/46), respectively (Figure 1). The seh and sea were the most frequent genes observed in the cow isolates. Different from those found in cows isolates, sec was the only $S$. aureus enterotoxin gene found in goat isolate.

The identification of classical enterotoxin genes is important as a basis for determining the enterotoxin gene related familial relationships. Studies on the overall super antigenic toxin genes can be used to know the pathogenesis of $S$. aureus and can give some advantages in diagnostic, epidemiological, and medical purposes $[10,18]$. The virulence factors of $S$. aureus, such as $\beta$-hemolysin and SEs can be applied in constructing the appropriate steps of treatment [19].

The early outbreaks of food poisoning were mostly caused by classical enterotoxin genes (sea-see and seh) [20]. In this study, the most commonly se gene in $S$. aureus isolates from cows was seh gene, followed by the sea gene. This result is different from the information about the enterotoxin genes found in other countries, where sea gene is the dominant gene and frequently found in foodborne disease cases. The food poisoning outbreak occurred in Japan in 2000 was known to be caused by the sea gene that resistant to high temperatures [6]. The sec, sea, sed, ser, and $s e j$ where the mostly found enterotoxin gene in Italy [7] and Iran [8].

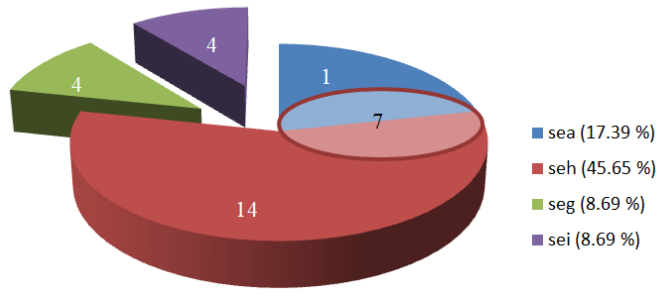

Figure 1 Distribution of $S$. aureus enterotoxin genes from cows. Seven isolates had a combination of sea and seh genes, while others had a single enterotoxin gene.
The seh gene produces cytotoxic effects and induces apoptosis on bovine mammary epithelial cells (bMECs) in mastitis cases [21]. Negative effect due to seh gene can emerge in low bacterial concentration. Therefore, in an environmental condition that is not optimum for the growth of $S$. aureus, the potential health risks of seh gene is still exist [22].

In several recent cases of poisoning caused by $S$. aureus, it is known that the dominant causative toxin are seg, sei, sem, sen, seo, seu, but not the sea-see genes [23]. Similar finding is also reported in China, where the seg-seu toxin genes were found more frequently than the sea-sed whilst see and seh gene were absence in all isolates [9]. However, from the harmful effects, the occurrence of seg and sei genes is more important due to their potential in stimulating $\mathrm{T}$ cell proliferation and inhibiting K562 and B16 cells proliferations. In the future, proteins with this kind of function can be used in drug development and cancer therapy [24].

A different pattern of enterotoxin distribution reported by Mehli et al. [25], where $87.5 \%$ of $S$. aureus isolated from cow milk and its processed products have sec gene, followed by seg and seh genes. In our study, the sec gene was only found in two $S$. aureus isolates from goat milk. This gene is of concern because it is commonly found in goat mastitis [26] and in the methicillin-resistant $S$. aureus group isolated from patients with prosthetic valve endocarditis (PVE) [27]. Basically, there are five genes with the highest virulence in goat milk, including Panton-Valentine Leukocidin ( $p v l)(29.5 \%)$, sec (23.2\%), ser (16.8\%), tst (14.7\%), and seb (12.6\%) [28].

\section{CONCLUSION}

The genes encoding four out of nine classical enterotoxins (seh, sea, seg, and sei) are commonly isolated from $S$. aureus in cow milk, but only sec gene can be found in the isolates from goat milk.

\section{AUTHORS' CONTRIBUTIONS}

DCW, SW, FA, and SIOS are equally contributed to this work. 


\section{ACKNOWLEDGMENT}

This research was partly supported by Ministry of Research and Technology of Higher Education through the PDUPT No. 2749/UN1.DITLIT/DIT-LIT/PT/2020.

\section{REFERENCES}

[1] A. Hachemi, S. Zenia, M.F. Denia, M. Guessoum, M.M. Hachemi, K. Ait-Oudhia, Epidemiological study of sausage in Algeria: Prevalence, quality assessment, and antibiotic resistance of Staphylococcus aureus isolates and the risk factors associated with consumer habits affecting foodborne poisoning, Vet. World 12(8) (2019) 1240-1250.

DOI:https://doi.org/10.14202/vetworld.2019.12401250.

[2] R. Nazari, H. Godarzi, F.R. Baghi, M. Moeinrad, Enterotoxin gene profiles among Staphylococcus aureus isolated from raw milk, Iranian J. Vet. Res. 15(4) (2014) 409.

[3] N. Ertas, Z. Gonulalan, Y. Yildirim, E. Kum, Detection of Staphylococcus aureus enterotoxins in sheep cheese and dairy desserts by multiplex PCR technique, Int. J. Food Microbiol. 142(1-2) (2010) 74-77. DOI: https:// doi.org/10.1016/j.ijfoodmicro.2010.06.002.

[4] S. Johler, D. Weder, C. Bridy, M.C. Huguenin, L. Robert, J. Hummerjohann, R. Stephan, Outbreak of staphylococcal food poisoning among children and staff at a Swiss boarding school due to soft cheese made from raw milk, J. Dairy Sci. 98(5) (2015) 2944-2948. DOI: https:// doi.org/10.3168/jds.2014-9123.

[5] S.D. Saei, M. Ahmadi, A.S. Farahmand, E. Anassori, Identification of toxic shock syndrome toxin-1 (TSST-1) gene in Staphylococcus aureus isolated from bovine mastitis milk, Sci. Inform. Database 68(1) (2013) 17-22. DOI: https://doi.org/10.7508/ARI.2013.01.003.

[6] I.I. Sabike, H. Fujikawa, M.Z. Sakha, A.M. Edris, Production of Staphylococcus aureus enterotoxin a in raw milk at high temperatures, J. Food Protect. 77(9) (2014) 1612-1616. DOI: https://doi.org/10.4315/0362-028X.JFP-13-527.

[7] V. Carfora, A. Caprioli, N. Marri, D. Sagrafoli, C. Boselli, G. Giacinti, G. Giangolini, L. Sorbara, S. Dottarelli, A. Battisti, S. Amatiste, Enterotoxin genes, enterotoxin production, and methicillin resistance in Staphylococcus aureus isolated from milk and dairy products in Central Italy, Int. Dairy
J. 42 (2015) 12-15. DOI:

https://doi.org/10.1016/j.idairyj.2014.10.009

[8] N. Sahebekhtiari, Z. Nochi, M. Eslampour, H. Dabiri, M. Bolfion, M. Taherikalani, B. Khoramian, M. Zali, M. Emaneini, Characterization of Staphylococcus aureus strains isolated from raw milk of bovine subclinical mastitis in Tehran and Mashhad, Acta Microbiol. Immunol. Hungarica. 58(2) (2011) 113-121. DOI: https://doi.org/10.1556/AMicr.58.2011.2.4.

[9] J. Tang, C. Tang, J. Chen, Y. Du, X.N. Yang, C. Wang, H. Zhang, H. Yue, Phenotypic characterization and prevalence of enterotoxin genes in Staphylococcus aureus isolates from outbreaks of illness in Chengdu City, Foodborne Pathogens Dis. 8(12) (2011) 1317-1320. DOI: https://doi.org/10.1089/fpd.2011.0924.

[10] K. Omoe, D.L. Hu, H. Takahashi-Omoe, A. Nakane, K. Shinagawa, Comprehensive analysis of classical and newly described staphylococcal superantigenic toxin genes in Staphylococcus aureus isolates, FEMS Microbiol. Letters. 246(2) (2005) 191-198. DOI: https://doi.org/10.1016/j.femsle.2005.04.007.

[11] S.I.O. Salasia, Khusnan, C. Lammler, M. Zshock, Comparative studies on pheno- and genotypic properties of Staphylococcus aureus isolated from bovine subclinical mastitis in Central Java, Indonesia and Hesse, Germany, J. Vet. Res. Sci. 5(2) (2004) 103-109. DOI: https://doi.org/10.4142/jvs.2004.5.2.103.

[12] S. Windria, D.C. Widianingrum, S.I.O. Salasia, Identification of Staphylococcus aureus and coagulase negative Staphylococci isolates from mastitis milk of Etawa Crossbred Goat, Res. J. Microbiol. 11(1) (2016) 11. DOI: https://doi.org/10.3923/jm.2016.11.19

[13] K. Omoe , M. Ishikawa, Y. Shimoda, D.L. Hu, S. Ueda, K. Shinagawa, Detection of seg, seh, and sei genes in Staphylococcus aureus isolates and determination of the enterotoxin productivities of S. aureus isolates harboring seg, seh, or sei genes, J. Clin. Microbiol. 40(3) (2002) 857-862. DOI: https://doi.org/10.1128/JCM.40.3.857-862.2002

[14] J.A. Straub, C. Hertel, W.P. Hammes, A 23S rDNA-targeted polymerase chain reaction-based system for detection of Staphylococcus aureus in meat starter cultures and dairy products, J. Food Prot. 62 (1999) 1150-1155. DOI: https://doi.org/10.4315/0362-028x-62.10.1150.

[15] O.G. Brakstad, K. Aasbakk, J.A. Maeland, Detection of Staphylococcus aureus by 
polymerase chain reaction amplification of the nuc gene. J. Clin Microbiol. 30(7) (1992) 1654-1660.

[16] J.V. Hookey, J.F. Richardson, B.D. Cookson, Molecular typing of Staphylococcus aureus based on PCR restriction fragment length polymorphism and DNA sequence analysis of the coagulase gene, J. Clin. Microbiol. 36(4) (1998) 1083-1089.

[17] K. Becker, R. Roth, G. Peters, Rapid and specific detection of toxigenic Staphylococcus aureus: use of two multiplex PCR enzyme immunoassays for amplification and hybridization of staphylococcal enterotoxin genes, exfoliative toxin genes, and toxic shock syndrome toxin 1 gene, J. Clin. Microbiol. 36(9) (1998) 2548-2553. DOI: https://doi.org/10.1128/JCM.36.9.2548-2553.1998.

[18] L. Oliveira, A.C. Rodrigues, C. Hulland, P.L. Ruegg, Enterotoxin production, enterotoxin gene distribution, and genetic diversity of Staphylococcus aureus recovered from milk of cows with subclinical mastitis, Am. J. Vet. Res. 72(10) (2011) 1361-1368. DOI: https://doi.org/10.2460/ajvr.72.10.1361.

[19] W.J. van Wamel, S.H. Rooijakkers, M. Ruyken, K.P. van Kessel, J.A. van Strijp, The innate immune modulators staphylococcal complement inhibitor and chemotaxis inhibitory protein of Staphylococcus aureus are located on $\beta$ hemolysin-converting bacteriophages, J. Bacteriol. 188(4) $2006 \quad 1310-1315 . \quad$ DOI: https://doi.org/10.1128/JB.188.4.1310-1315.2006.

[20] M.A. Argudín, M.C. Mendoza, M.R. Rodicio, Food poisoning and Staphylococcus aureus enterotoxins, Toxins 2(7) (2010) 1751-1773. DOI: https://doi.org/10.3390/toxins2071751.

[21] Y. Liu, W. Chen, T. Ali, R. Alkasir, J. Yin, G. Liu, B. Han, Staphylococcal enterotoxin $\mathrm{H}$ induced apoptosis of bovine mammary epithelial cells in vitro, Toxins 6(12) (2014) 3552-67. DOI: https://doi.org/10.3390/toxins6123552.

[22] E. Lis, M. Podkowik, J. Bystron, T. Stefaniak, J. Bania, Temporal expression of staphylococcal enterotoxin $\mathrm{H}$ in comparison with accessory gene regulator-dependent and -independent enterotoxins, J. Food Protec. 75(2) (2012) 238 244. DOI: https://doi.org/10.4315/0362-028X.JFP11-336.

[23] K. Umeda, H. Nakamura, K. Yamamoto, N. Nishina, K. Yasufuku, Y. Hirai, T. Hirayama, K. Goto, A. Hase, J. Ogasawara, Molecular and epidemiological characterization of staphylococcal foodborne outbreak of Staphylococcus aureus harboring seg, sei, sem, sen, seo, and selu genes without production of classical enterotoxins, Int. J. Food Microbiol. 256 (2017) 30-35. DOI: https://doi.org/10.1016/j.ijfoodmicro.2017.05.023.

[24] B. Chen, M. S. Akash, K. Rehman, H. Sun, S. Chen, Expression and bioactivity analysis of staphylococcal enterotoxin $\mathrm{G}$ and staphylococcal enterotoxin I, Pharm. Biol. 52(1) (2014) 8-13. DOI: https://doi.org/10.3109/13880209.2013.804845.

[25] L. Mehli, S. Hoel, G.M. Thomassen, A.N. Jakobsen, H. Karlsen, The prevalence, genetic diversity and antibiotic resistance of Staphylococcus aureus in milk, whey, and cheese from artisan farm dairies, Int. Dairy J. 65 (2017) 20-7.

DOI:

https://doi.org/10.1016/j.idairyj.2016.10.006

[26] C. Chu, C. Yu, Y. Lee, Y. Su, Genetically divergent methicillin-resistant Staphylococcus aureus and sec-dependent mastitis of dairy goats in Taiwan, BMC Vet. Res. 8(1) (2012) 39. DOI: https://doi.org/10.1186/1746-6148-8-39.

[27] H. Kitagawa, H. Ohge, J. Hisatsune, T. Kajihara, K. Katayama, S. Takahashi, T. Sueda, M. Sugai, Prosthetic valve endocarditis caused by ST8 SCCmecIV1 type community-associated methicillin-resistant Staphylococcus aureus: a case report. Internal Med. (2019)1415-1418. DOI: https://doi.org/10.2169/internalmedicine.

[28] X. Xing, Y. Zhang, Q. Wu, X. Wang, W. Ge, C. $\mathrm{Wu}, \quad$ Prevalence and characterization of Staphylococcus aureus isolated from goat milk powder processing plants. Food Control 59 (2016) 644-650.

DOI: https://doi.org/10.1016/j.foodcont.2015.06.042. 